\title{
The Innovation and Reform of Talent Cultivation Model of Application Technology Leisure Sports
}

\author{
Zhi-Chao MA \\ The School of Physical Education \\ Wuhan Business University \\ Wuhan, China \\ mazhichaocn@live.cn
}

\author{
Yun-Jian XIA \\ The School of Physical Education \\ Wuhan Business University \\ Wuhan, China \\ Xiayunjian2008whs@163.com
}

\begin{abstract}
The setting of leisure sports major in 2012 is a new measure in the sports development and opens up a new branch for the development of disciplines. The demand for application technology leisure sports professionals represents a sharp increasing trend, particularly those high-level talents with the professional knowledge and strong athletic skills keeping up with the times to break the traditional training pattern. The cultivation of such talents not only meets the needs of the times, but has a bright future. Based on the reality of the schoolenterprise cooperative mechanism of the application technology talents in China and by combining with the experience of Sports Academy of Wuhan Business University in horse racing (equestrianism) personnel training aspect, this paper discusses the present situation of application technology leisure sports talents cultivation mode and school-enterprise cooperation way, draws beneficial lessons from the foreign school-enterprise cooperation mode and further puts forward countermeasures and suggestions for China's application technology leisure sports training model.
\end{abstract}

Keywords-application technology; school-enterprise cooperation; talent cultivation

\section{INTRODUCTION}

The talents cultivation is a current demand for a country to enhance the comprehensive national strength and also the demand of talents represents the diversified and multi-level trend in the era of knowledge economy. The economic take-off and industrial upgrading not only require $\mathrm{R} \& \mathrm{D}$ talents with knowledge and science creation abilities in the traditional sense, but the application technology talents in the knowledge transfer, diffusion and application areas. However, the cultivation of application technology talents occupying most of higher education is still not enough and perfect due to the lack of attention on its gradation and difference [1].This has seriously affected our transformation from a country with huge human resources to a great power by developing human resources, and not conducive to the comprehensive national strength, economic take-off and industrial transformation in the era of knowledge economy.

The prosperous social economy is inseparable from the development level of higher education and the talents should adapt to the social and economic development, therefore, it is very necessary to meet the dynamic industrial structure and

Technology Innovation Projects of Wuhan Business University (No.2016kc03), Colleges and Universities Outstanding Youth and Middle Age Scientific and Technological Innovation Team Project of Hubei Province (T201628) change needs for the application technology talents in the social economic development. How to cultivate application technology talents in line with the requirements of the twentyfirst century has put forward higher and more urgent requirements for higher education in China, and become the focus of society and higher education.

\section{Development Present Situation of Application TeChNOLOgy TALENT Cultivation Model IN CHINA}

A. Rapid Development of China's Strategy of Invigorating the Country through Science and Education and ApplicationOriented Undergraduate Colleges

China has had a huge demand for higher education system reform since the end of the last century. China's higher education has begun to inject new blood and emerged a number of undergraduate colleges established by colleges independently and approved by the Ministry of Education due to newer and higher demands of social economic development for the traditional higher education model. These colleges always adhere to "application-oriented", gear to the regional economic society mainly based on undergraduate education and application professional education and take the social talents demand as the guide to cultivate high-end application talents, which are often referred to as "application undergraduate colleges"[2].Their fundamental idea is to serve the local, which is a foothold of survival and development and the stance of deepening reform.

\section{B. Demand for Application Technology Talents under the New Situation}

The higher education in China has appeared a period of scale rapid expansion under the influences of the national transition, scientific and technological progress, economic development, educational democratization and other factors since 1999. However, the development of social productive forces, the continuous emerging industries and the changing labor force market demand have pushed forward the traditional structure and model reform of higher education. Therefore, higher education has to walk out of "ivory tower" and conducts close cooperation with society. The social service function of colleges and universities has been strengthened, even including the function and connotation of the talent cultivation and 
scientific research, and China's higher education is changing towards the diversification [3].

The colleges training application technology talents and the enterprises employing them are the two main bodies and they are indispensable and irreplaceable according to the theory of human capital. Therefore, as one of the main ways to cultivate the application technology talents, the school-enterprise cooperation will guide and promote the transformation and development of local colleges and universities to the application technology types, enhance their abilities to support industrial upgrading, technological progress and social management innovation, improve modern vocational education system, promote the development of higher education characteristics, and further promote the construction of learning society.

The cultivation of high-end leisure sports talents ushered in a turning point in history facing the development opportunity of the talents training mode transformation. The leisure sports professional set in 2012 is a new measure in the sports development in China and opens up a new branch for the disciplines development. As a inter-disciplinary professional, leisure sports is both inseparable from sports and leisure, and physical exercise, sports and leisure have become important parts of the modern service industry along with the rapid development of China's economy and the improvement of people's living standards. The demand for application technology leisure sports professionals represents a sharp increasing trend, particularly those high-level talents with the professional knowledge and strong athletic skills keeping up with the times to break the traditional training pattern. The cultivation of such talents not only meets the needs of the times, but has a bright future.

\section{Core of Many Difficulties and Problems in the Current Application Technology Talent Cultivation}

At present, the reality of application undergraduate colleges development and application technology talents cultivation is not optimistic and still faces considerable problems.

The research on the application undergraduate colleges development shows that the environmental pressure brought by the government requirement, regional social and economic development ,academic standards and value control are the key factors influencing the differentiation and dedifferentiation in higher education system[4].There is the serious convergence in the application undergraduate colleges practice that many universities pursue diversified management while conducting repeated construction in disciplines and professionals, meaning the diversification and homogenization coexistence in higher education. On the other hand, a considerable part of application local undergraduate colleges focus on "theory" instead of "practice", stress complete disciplines, high teaching level, large development scale and take the traditional colleges as the important reference. This kind of education model, which is obviously contrary to the diversified requirements of the higher education popularization leads to the lack of development path and model deviating from the educational goals. In addition, China's education authorities lack accurate scientific planning and classification guidance on the development of various colleges and universities, and the current unified evaluation criteria is not conducive to diversification of application undergraduate colleges, while the single assessment main body is also not conducive to the formation of pluralistic values for application technology talents.

In the application technology talents cultivation model, the backward educational philosophy and lack of teaching conditions lead to that the cultivation model still focuses on teachers ignore practice. Actually domestic college teachers lack relevant work experience seriously, while many domestic enterprises often do not want to participate in school teaching and practice due to various reasons, even the talent cultivation model in our country is not conducive to employees' further study. Consequently, there are many problems and constraints in the cultivation process of application technology talents, such as the great difference between students and the requirements of enterprises, the outdated curriculum system and unreasonable curriculum configuration, so it is very necessary to improve the teaching methods, the quality of teachers and the application technology talents evaluation mechanism.

\section{Establishment and Its Necessity of Application Technology Talent Cultivation Mode}

During the higher education great-leap-forward development in more than ten years, China's gross enrollment rate of higher education has increased from 8.8\% in 1997 to $37.5 \%$ in 2014 and the total size of higher education reached 33.59 million[5], especially the number of students in application technology undergraduate colleges increasing significantly. The Ministry of Education intends to conduct the colleges and universities reform and transform more than 600 to vocational education in 1200 ordinary colleges [6]. This shows that the application undergraduate colleges already undertake China's higher undergraduate education mission in the era of higher education popularization.

The popularization of higher education will inevitably lead to its transformation, require fully integrating into the social economic development, meeting the needs of popular higher education, changing the traditional elite education to mass education and building a diversified higher education development model, but the important trend is that higher education must focus on the application technology talents cultivation. In fact, the higher education has formed the consensus that the higher education popularization not only means the scale expansion, but the nature changes, and one of the most important is the diversification of cultivation objectives and types of talents. In 1978, Deng Xiaoping pointed out that "education should have a great development and improvement "and our country is facing a serious problem, the lack of talents, and we cannot achieve grand blueprint without large number of talents. There is still a big gap between the application technology talents cultivation in China and that of developed countries and we should improve the overall quality of labor force to realize the transformation from a country with huge human resources to a great power by developing human resources, and local application undergraduate colleges mainly undertake the important task. As the application undergraduate colleges are mostly 
subordinate to the local governments and are closely related to the regional economic society, this will directly cultivate suitable application technology talents, in order to facilitate regional knowledge innovation and transmission.

\section{EXPLORATION AND INNOVATION OF OUR ACADEMY IN THE HORSE RACING (EQUESTRIANISM) TALENT CULTIVATION PRACTICE}

\section{A. Exploration and Innovation of "School-Government, School-Enterprise Dual Orientation (Order) Mutual Aid " Talent Cultivation Mode}

Some technicians in the Sports Academy of Wuhan Business University, the government, industry and association initially determine basic technical post classification in the horse racing industry through the analysis on horse racing post, analyze the equipped professional skills and knowledge of talents through the statistics of technical post in the horse racing industry and discuss the supported curriculum system to make talents training directly gear to the market and cultivate the application high-quality talents. In order to enable students in horse racing (equestrianism) professional meet the market requirements, the Sports Academy of Wuhan Business University has successively signed the joint agreement with the Wuhan Sports Bureau, the Chinese Equestrian Association, Wuhan Jockey Club Co., Ltd., Beijing Equuleus International Riding Club and Tianjin HuanYa International Polo Club, taken the "school-government, school-enterprise dual orientation (order) mutual aid training" to cultivate and strengthen the general knowledge and vocational technical ability, determined the short, medium and long-term goals of specific sports industry talents cultivation, encouraged schoolgovernment, school-enterprise to establish the long-term exchanges and cooperation and ultimately realized talents cultivation model in school-government and industryuniversity-research.

The Sports Academy of Wuhan Business University has always paid attention to innovative management philosophy, opening up new ideas, implementing new mechanisms and adopting new models in the process of cultivating students. Wuhan Business University has launched "jockey class" with Wuhan Jockey Club jointly since April 2009 and selected about 25 students annually. These students first have 18-month skill training in the Orient Horse City, then experience a probationary period in the second stage and ultimately become the real "jockey" after more than a year of studies. The Sports Academy of Wuhan Business University has selected sophomore students majoring in horse racing industry management of social sports to participate in "takeoff plan" equestrianism and speed training courses and conduct joint cultivation who can directly work in horse field after graduation since 2010 .

\section{B. Assisting Students to Conduct Multiple Practices While Learning the Theories}

The Sports Academy of Wuhan Business University adheres to the practical principle, constructs the practical teaching system based on the working process and task and characterized by pertinence, application and practicality, focuses on the combination of teaching and practice and stresses the practical teaching in the curriculum setting and class allocation, especially making practical teaching links not less than $60 \%$ of the total plan. Taking horse racing (equestrianism) major as an example, the Sports Academy relies on excellent practice teaching conditions in the East Horse City and the school horse field, sets courses in horse racing organization and management, stable management, horse training theory and practice and riding training and guidance, selects professional technical personnel to teach together with the school teachers, increases the courses in practice teaching, emphasizes the combination of teachinglearning-doing to ensure systematical cultivation of students' job skills. It fully utilizes the advantages of annual Wuhan International Jockey Festival in October, arranges students majoring in horse racing industry management to participate in supporting work, conducts field teaching by combining with the actual job tasks, effectively realizes the job training before the contest, teachers guidance in the contest and teacherstudent exchange (including part-time teachers) after the contest and earnestly implements the teaching characteristics of "teaching-learning-doing" especially in the training programs; in addition, it organize students to participate in the referee supporting in the national horse races under the arrangement of China Horse Industry Association, especially students majoring in horse racing industry management to carry out social practice activities and take part in the work of various departments in the summer. The Sports Academy of Wuhan Business University has continuously expanded the practice methods of students in the horse racing industry management and enhanced the linking theory with practice ability of students majoring in horse racing industry management of the social sports according to the requirements of the personnel training program jointly developed by the school and enterprise.

\section{Strengthening "Double-Position" Teachers Team Construction}

The construction of double-position teacher team is the requirement of adjusting the application technology undergraduate colleges idea and cultivating application technology talents. It is very essential to achieve teachers training integration, strengthen the cooperation between colleges and local enterprises, arrange professional teachers to practice in enterprises, adhere to the combination of "sending out, and coming in" and "full-time training and independent learning", change the knowledge structure with strong theories, but relatively weak practice, work closely with enterprises and fully use excellent teachers' influences in horse racing industry management professional, in order to build a teaching team with high professional level and quality, excellent structure, good teaching effect, unique research and scientific research results and further achieve "school- enterprise interaction, fullpart time combination and dynamic composition".

\section{Promoting the Leisure Sports Teaching Materials and Cultivating "Happy Learning Concept" of Students}

The Sports Academy of Wuhan Business University has proposed the leisure teaching materials for the reform of highend leisure sports talent cultivation model. The leisure feature means a process to have a reasonable transformation, 
processing, refining and sublimation on course contents and further cultivate students according to the modern educational ideas and scientific sports methods, principles and human development law. Colleges and universities can proceed from the reality and focus on students' interests and demands, the social popular activities and teaching contents adapting to the future occupation, so that students can experience the fun of learning knowledge in "entertainment" and actively master instead of the passive teaching. This kind of talent cultivation model aims can let students experience the learning fun and stimulate their interest and experience happy learning, understand and knowledge mastering, so as to stimulate their learning initiative from the perspective of lifelong learning and harmonious development, which can be called "happy learning thinking "compared with the traditional teaching mode.

\section{CONCLUSION}

There is a huge demand for high-end leisure sports talents in China due to the rapid development in leisure sports industry, therefore, it is very necessary to focus on the market demand, open up innovation and highlight the characteristics according to the features of application technology undergraduate colleges; in addition, it is essential to jointly develop personnel training program, build the curriculum system, share teaching resources according to requirements of the employers, cultivate high-end leisure sports talents based on the new talent training mechanism and further facilitate better and faster development of leisure sports industry in China.

\section{REFERENCES}

[1] XP Yan, XM Chen. "Application Technology Development Road of Colleges to Deepen the Reform," China Higher Education, vol. Z2, pp. 58-60, March 2014.

[2] CY Xiao. "Research on the Application Technology Talent Cultivation and its Values," Research in Education Development, vol. 24, pp. 68-73, July 2005.

[3] L Yang. "The Transformation from Local Undergraduate Colleges to Application Technology Universities: Inevitable Trends, Problems and Practice Paths,” Journal of HONGHE University,vol. 2, pp. 110-114, Janorary 2015.

[4] P Xu. "The Diversified Development Process and Promotion Strategy of Higher Education,” Educator, vol. 3, pp. 8-10, March 2010.

[5] Statistical Bulletin on National Education Development in 2014. [EB/OL]. [2015-09-07]. http: //news. Youth. cn/ jsxw/201507/t20150730_6940667.htm.

[6] YL Liu. Transformation of A Batch of Ordinary Undergraduate Colleges into Application Technology Universities. [EB/OL]. [2015-09-07]. http: //www. chsi.com.cn/jyzx/ 201406/ 20140627/1067885145.html 